\title{
KEBERFUNGSIAN AGAMA DI KELUARGA, ANCAMAN, INTERAKSI TEMAN SEBAYA, DAN RELIGIUSITAS REMAJA
}

\author{
Eko Yuliarti Siroj ${ }^{\left.{ }^{*}\right)}$, Euis Sunarti ${ }^{2}$, Diah Krisnatuti ${ }^{2}$ \\ ${ }_{1}^{1}$ Program Studi IImu Keluarga dan Perkembangan Anak, Sekolah Pascasarjana, Institut Pertanian Bogor, \\ Bogor 16680, Indonesia \\ ${ }^{2}$ Departemen IImu Keluarga dan Konsumen, Fakultas Ekologi Manusia, Institut Pertanian Bogor, \\ Bogor 16680, Indonesia
}

*)E-mail: eko_yuliarti@yahoo.com

\begin{abstract}
Abstrak
Religiusitas menjadi salah satu faktor penting dalam perkembangan remaja yang dipengaruhi oleh lingkungan terdekat, diantaranya keberfungsian agama di keluarga, faktor ancaman, dan interaksi dengan teman sebaya. Penelitian ini bertujuan menganalisis pengaruh karakteristik remaja, karakteristik ibu, keberfungsian agama di keluarga, ancaman, dan interaksi teman sebaya terhadap religiusitas remaja. Penelitian ini menggunakan desain cross sectional study pada 240 siswa kelas X yang memiliki keluarga utuh dan tinggal bersama kedua orang tuanya. Responden berasal dari dua sekolah menengah atas/SMA dan dua sekolah menengah kejuruan/SMK (negeri dan swasta) di Kota Bogor yang dipilih secara purposive dengan alasan sekolah terpilih memiliki siswa yang berasal dari status sosial ekonomi beragam. Data diolah dengan menggunakan analisis deskriptif dan analisis inferensial (uji independent simple t-test dan uji regresi). Hasil penelitian menunjukan bahwa orang tua dari remaja siswa SMK melakukan keberfungsian agama lebih tinggi daripada orang tua siswa SMA. Remaja laki-laki mendapatkan ancaman yang lebih tinggi daripada remaja perempuan. Remaja siswa sekolah swasta melakukan interaksi dengan teman sebaya lebih tinggi daripada siswa sekolah negeri. Remaja laki-laki memiliki tingkat religiusitas lebih tinggi dibandingkan remaja perempuan. Remaja siswa SMK dan sekolah swasta memiliki religiusitas yang lebih tinggi dibandingkan siswa SMA dan siswa sekolah negeri. Usia remaja, keberfungsian agama dan interaksi remaja dengan teman sebaya berpengaruh positif terhadap religiusitas remaja. Jenis kelamin remaja, usia, dan pendidikan ibu tidak memberikan pengaruh terhadap religiusitas remaja.
\end{abstract}

Kata kunci : ancaman, interaksi teman sebaya, keberfungsian agama, religiusitas remaja

\section{Religious Function in Family, Threats, Peer Interaction, and Adoescent's Religiosity}

\begin{abstract}
Religiosity has become one of significant factors in adolescence's development, which is influenced by the closest environment among others including religion function in family, threat, and interaction factors with peers. This research aims were analyzing influence adolescence's characteristics, mother's characteristics, religion function in family, threat, and peers interaction on adolescence's religiosity. This research used cross sectional study design on 240 students of class X having intact family and living with both of their parents. The respondents come from two senior high schools and two vocational schools (public and private) in Bogor that are selected purposively because of variation of social and economic status of the families. Data was processed using descriptive analysis and inferential analysis (independent simple t-test and regression test). The result shows that parents of vocational schools' students had higher religion function. Boys had higher threats than girls. Private school students had higher interaction than public. Boys had higher religiosity than girls. Students of vocational school and private schools had higher religiosity than ones of senior high cchool and state school. Adolescent's age, religion function in family, and adolescents's interaction with their peers had significant influence on the religiosity of adolescents. Meanwhile, adolescent's sex, age and mother's education did not have influence on the religiosity of adolescents.
\end{abstract}

Keywords: adolescent's religiosity, peer interaction, religious function, threats

\section{PENDAHULUAN}

Dalam konteks budaya timur (Eastern cultures), pengamalan nilai-nilai agama di masyarakat menjadi bagian penting yang harus dipelajari oleh setiap individu. Agama membimbing seseorang di kehidupan sehari-hari untuk mencapai tujuan hidupnya. Bagi remaja dan pemuda, interaksi dengan agama adalah aset eksternal yang mendukung, memberdayakan, dan membimbing pengembangan diri yang konstruktif (Cheung \& Yeung, 2010). Kehadiran agama yang membimbing remaja dalam pengembangan dirinya sangat dibutuhkan karena masa remaja adalah masa transisi dari kanak-kanak menuju dewasa (Santrock, 2007) 
yang penuh dengan gejolak (Hurlock, 1993). Penelitian yang dilakukan Furrow, King, dan White (2004) menunjukan bahwa sumber daya ideologis yang diberikan agama memberikan gambaran untuk pembentukan identitas diri pada masa remaja. Religiusitas remaja adalah kepercayaan dan pengetahuan remaja terhadap Tuhan, kitab suci, dan ajaran agamanya yang terlihat dalam sikap menjalankan ajaran dan kewajiban-kewajiban yang bertalian dengan kepercayaan dan agamanya serta kesiapan menerima segala konsekuensinya (Alwi, 2014). Agama juga menjadi bagian yang penting dalam kehidupan keluarga dan pengasuhan anak. Orang tua memiliki peran penting dalam pembentukan religiusitas remaja (Leonard et al., 2013) yaitu dengan mengenalkan ajaran agama, memberikan contoh pelaksanaannya, dan membiasakan remaja untuk menjalankannya di keluarga. Internalisasi nilai kebaikan melalui fungsi keagamaan, yang dikenal sebagai internalisasi fungsi keagamaan, adalah proses penanaman nilai kebaikan melalui fungsi keagamaan keluarga (Dermawan, Sunarti, \& Herawati, 2018). Oleh karenanya, religiusitas yang dimiliki remaja berkaitan dengan keberfungsian agama yang dilakukan orang tua di keluarga (Vermeer, 2014).

Beberapa data dan informasi menunjukan berbagai permasalahan anak di Indonesia. Indonesia menduduki peringkat ke-3 dengan jumlah perokok terbesar di dunia setelah China dan India (WHO, 2008). Pada Tahun 2011 terjadi 335 kasus tawuran yang menyebabkan 82 anak meninggal dunia. Komisi Perlindungan Anak mencatat bahwa sepanjang Januari November 2013 terdapat 255 kasus tawuran pelajar di kota Jakarta (Aprilia \& Indrijati, 2014). Secara nasional, Tahun 2014 terdapat sekitar 4.200 kasus narkoba dan menurut data BNN Jawa Timur pengguna narkoba yang terbanyak adalah remaja dengan jenjang pendidikan SMA yaitu sebanyak 2.586 kasus (Junaidi, 2017). Dalam 229 kasus kekerasan antar pelajar SMP dan SMA itu, 19 siswa meninggal dunia (Sunarti et al., 2017). Beberapa fakta tersebut menggambarkan jika kerentanan dan ancaman yang dihadapi anak-anak Indonesia cukup tinggi. Ancaman adalah kejadian hidup atau pengalaman yang berhubungan dengan peningkatan permasalahan pada perilaku (Wardhani, Sunarti, \& Muflikhati, 2017). Ancaman dapat berasal dari diri individu remaja itu sendiri, keluarga, maupun masyarakat yang merupakan suatu prediktor awal dari sebuah hasil yang tidak menguntungkan dan sesuatu yang membuat orang menjadi rentan. Ancaman merujuk pada variabel yang mengarahkan pada ketidakmampuan atau mediator yang menyebabkan terjadinya suatu perilaku yang bermasalah (Kaplan, 1999). Faktor ancaman menjadi salah satu masalah yang membutuhkan perhatian dari orang tua dan orang dewasa di sekitar remaja. Tekanan dari kelompok remaja untuk kompak serta menuntut remaja untuk mengikuti kebiasaan yang berlaku di kelompok tersebut merupakan bentuk ancaman yang dihadapi remaja yang berasal dari kelompok teman sebayanya. Ancaman tersebut juga termasuk jika ada anggota kelompok yang mencoba minum alkohol, obatobatan terlarang, atau merokok; remaja cenderung mengikutinya tanpa memperdulikan perasaannya sendiri (Hurlock, 1993). Besarnya ancaman yang dihadapi remaja memungkinkan terjadinya perubahan pada tingkat religiusitasnya (Nisfiannoor \& Kartika, 2004).

Remaja dalam memilih teman akan memiliki kesamaan dengan dirinya untuk menemukan identitas dan kemandiriannya melalui lima dimensi yaitu persahabatan, konflik, bantuan, kedekatan, dan rasa aman (Bukowski, Hoza, \& Boivin,1994). Status teman sebaya adalah sebuah konstruksi multidimensi yang mencerminkan posisi sosial seorang individu dalam kelompok sebayanya (Borch, Hyde, \& Cillessen, 2011). Interaksi dengan teman sebaya seringkali berfungsi positif bagi remaja, namun beberapa penelitian menyatakan bahwa interaksi dengan teman sebaya juga mendatangkan aspek negatif dengan cara mengenalkan nilai-nilai negatif tersebut (Nisfiannoor \& Kartika, 2004).

Jessor (1976) memberikan penjelasan bahwa remaja bukan pengguna narkoba memiliki religiusitas tinggi dan pengguna narkoba cenderung memiliki religiusitas rendah. Para ahli mendefinisikan religiusitas sebagai keberagamaan sesuai dengan agama yang dianut masing-masing individu. Anshari (1987) membedakan antara istilah religi atau agama dengan religiusitas atau keberagamaan. Agama menunjukkan aspek-aspek formal yang berkaitan dengan aturan dan kewajiban, sedangkan religiusitas menunjukkan aspek religi yang telah dihayati oleh seseorang di dalam hatinya sehingga melahirkan amal/aktifitas tertentu sesuai tuntunan agamanya. Sejumlah peneliti lain melaporkan adanya hubungan terbalik antara religiusitas dan penggunaan narkoba remaja (Bahr et al., 2014). Namun di sisi lain, fenomena sikap acuh dan jauh dari ajaran agama juga semakin terlihat. Data BPS tahun 2009-2015 menunjukkan tingkat partisipasi pemuda dalam kegiatan keagamaan tiap tahun semakin 
menurun, dari 67,18 persen pada tahun 2009 menjadi 51,72 persen pada tahun 2015 (BPS, 2017).

Berdasarkan paparan sebelumnya, jika remaja memiliki religiusitas maka akan dapat menghindari dan mencegah perilaku negatif. Remaja saat melalui masa krisisnya membutuhkan panduan yang kuat berupa nilainilai agama yang didapatkan dari sosialisasi orang tua dan interaksi dengan teman sebaya. Faktor ancaman yang mengajak remaja pada perilaku negatif menjadi faktor yang penting untuk dianilisis sehingga remaja memiliki kemampuan untuk menghadapi ancaman yang dihadapinya dan tidak berpengaruh pada religiusitasnya. Berdasarkan uraian tersebut penelitian ini bertujuan untuk menganalisis perbedaan karateristik remaja, karakteristik keluarga, keberfungsian agama di keluarga, ancaman, interaksi remaja dengan teman sebaya dan religiusitas remaja berdasarkan jenis kelamin remaja serta status dan jenis sekolah. Selain itu, penelitian ini juga bertujuan untuk menganalisis pengaruh karakteristik remaja, karakteristik ibu, keberfungsian agama di keluarga, ancaman, dan interaksi remaja dengan teman sebaya terhadap religiusitas remaja.

\section{METODE}

Penelitian ini menggunakan desain cross sectional study di empat (4) tempat yaitu dua (2) sekolah menengah atas (SMA) terdiri dari SMA negeri dan SMA swasta dan dua (2) sekolah menengah kejuruan (SMK) terdiri dari SMK negeri dan SMK swasta di Kota Bogor. Pemilihan sekolah dilakukan secara purposive dengan pertimbangan bahwa sekolah yang terpilih memiliki peserta didik yang berasal dari status sosial ekonomi yang beragam. Pemilihan lokasi dilakukan secara purposive dengan pertimbangan bahwa Kota Bogor merupakan wilayah perkotaan dan identik dengan kota penyangga ibukota dengan kompleksitas masalah remaja yang banyak dan beragam.

Populasi penelitian adalah remaja dari keluarga utuh yang duduk di sekolah menengah atas (SMA) dan sekolah menengah kejuruan (SMK) terpilih. Kerangka contoh dalam penelitian ini adalah peserta didik kelas $X$ sesuai kriteria populasi di keempat sekolah terpilih. Sekolah yang dijadikan tempat penelitian ini dipilih secara purposive dengan kriteria sekolah memiliki peserta didik dari latar belakang sosial ekonomi yang beragam. Contoh dipilih dari siswa yang memiliki orang tua utuh dan tinggal beserta kedua orang tuanya dari kerangka contoh yang ditetapkan; kemudian ditentukan secara disproporsional stratified random sampling sebanyak 60 contoh dari setiap sekolah sehingga seluruhnya berjumlah 240 contoh. Unit analisis dalam penelitian ini adalah keluarga dan respondennya adalah remaja yang duduk di kelas $X$ beserta orang tuanya (ibu).

Pengumpulan data dilakukan secara langsung melalui selfreport oleh remaja dan ibu dengan alat bantu kuesioner terstruktur. Data primer yang dikumpulkan meliputi karakteristik keluarga terdiri atas usia ayah dan ibu serta pendidikan ayah dan ibu; karakteristik remaja yang terdiri atas usia, jenis kelamin dan urutan kelahiran; keberfungsian agama di dalam keluarga; ancaman, interaksi teman sebaya dan religiusitas remaja.

Keberfungsian agama adalah berjalannya aktivitas keagamaan dan terpeliharanya nilainilai agama di dalam keluarga yang dilakukan oleh seluruh anggota keluarga (Dermawan, Sunarti, \& Herawati, 2018). Keberfungsian agama diukur dengan menggunakan kuesioner internalisasi keberfungsian agama di keluarga yang dimodifikasi dan dikembangkan oleh Dermawan (2017) dari Konsep Dimensi Keberagamaan yang dimiliki Glock dan Stark (1968) dan terdiri dari lima dimensi, yaitu : dimensi keimanan (5 pernyataan) yang berkaitan dengan keyakinan terhadap nilai dan kebenaran Tuhan dan agama, dimensi pengetahuan ( 5 pernyataan) yang berkaitan dengan pengetahuan terhadap ajaran agama, dimensi pengalaman (5 pernyataan) yang berkaitan dengan pengalaman dalam menjalankan ajaran agama, dimensi ritual (5 pernyataan) yang berkaitan dengan pelaksanaan ritual ibadah, dan dimensi konsekuensi sosial (5 pernyataan) yang berkaitan dengan kesiapan menerima konsekwensi dari agama yang dianutnya. Instrumen keberfungsian agama terdiri dari 25 pernyataan dengan pengukuran menggunakan skala Likert, yaitu dari tidak pernah $($ skor $=0$ ), jarang (skor $=1$ ), sering (skor $=2$ ), hingga selalu (skor $=3$ ) dengan nilai Cronbach's Alpha 0,850 .

Ancaman adalah kejadian hidup atau pengalaman yang berhubungan dengan meningkatnya permasalahan pada perilaku remaja (Wardhani et al., 2017) yang berasal dari teman sebaya berupa ajakan atau paksaan untuk melakukan perilaku negatif seperti merokok, minum minuman keras, konsumsi narkoba, dan seks bebas. Ancaman menjadi sesuatu yang bersumber dari teman sebaya 
dan diukur menggunakan instrumen yang dikembangkan oleh Sunarti, Rochimah, dan Islamia (2015) terdiri dari 13 pernyataan. Skala pengukurannya adalah "Ya" (skor = 1) dan "Tidak" (skor $=0$ ), sehingga skor minimal dalam instrument ini adalah 0 dan skor maksimal 13 dengan nilai Cronbach's alpha 0,616.

Interaksi dengan teman sebaya adalah kedekatan remaja dengan teman atau remaja lainnya yang memiliki usia atau tingkat kematangan kurang lebih sama (Santrock, 2007). Variabel ini diukur menggunakan instrumen yang dikembangkan dari The Friendship Quality During Pre and Early Adolescence (Bukowski, 1994) yang terdiri dari 5 dimensi, yaitu persahabatan (4 pernyataan), konflik (4 pernyataan), bantuan (5 pernyataan), kedekatan ( 5 pernyataan), dan rasa aman (5 pernyataan). Instrumen ini terdiri dari 23 pernyataan dengan pengukuran menggunakan skala Likert, yaitu dari tidak pernah (skor=0), jarang $($ skor $=1)$, sering $($ skor $=2)$, hingga selalu (skor=3) dengan nilai Cronbach's alpha 0,787.

Religiusitas remaja diukur dengan menggunakan instrumen yang dimodifikasi dari Scale Religiositas (Glock \& Stark, 1968) yang terdiri dari lima dimensi, yaitu dimensi keyakinan/ideologis (6 pernyataan) yang berkaitan dengan keyakinan terhadap nilai dan kebenaran Tuhan dan agama; dimensi praktek agama/ritualistik (5 pernyataan) yang berkaitan dengan pelaksanaan ritual ibadah; dimensi pengalaman (5 pernyataan) yang berkaitan dengan pengalaman individu dalam menjalankan ajaran agamanya; dimensi konsekuensi (6 pernyataan) yang berkaitan dengan kesiapan individu menerima konsekuensi dari agama yang dianutnya; dan dimensi pengetahuan agama (6 pernyataan) yang berkaitan dengan pengetahuan individu terhadap ajaran agamanya. Pernyataan berjumlah 28 dengan pengukuran menggunakan skala Likert, yaitu dari tidak pernah (skor $=0$ ), jarang (skor $=1$ ), sering (skor $=2$ ), hingga selalu (skor $=3$ ) dengan nilai Cronbach's alpha 0,704.

Data selanjutnya diolah dan dianalisis melalui Microsoft Excel dan SPSS for Windows. Proses pengolahan data meliputi editing, coding, entry, scoring, dan analyzing. Pengolahan data dilakukan dengan menggunakan analisis deskriptif dan analisis inferensial. Analisis deskriptif (rata-rata, nilai minimum, nilai maksimum, dan kategori/persentase) untuk mengidentifikasi karakteristik remaja (usia, jenis kelamin, urutan kelahiran, pendidikan), karakteristik keluarga (usia ayah, usia ibu, pendapatan keluarga, pendidikan orangtua, dan besar keluarga), keberfungsian agama, ancaman, interaksi teman sebaya dan religiusitas remaja. Analisis inferensial berupa uji independent simple t-test digunakan untuk menguji perbedaan variabel keberfungsian agama di keluarga, ancaman, interaksi teman sebaya, dan religiusitas remaja berdasarkan jenis kelamin remaja serta status dan jenis sekolah. Sementara itu, uji inferensial berupa uji regresi digunakan untuk menguji pengaruh semua variabel bebas dalam penelitian ini terhadap religiusitas remaja.

\section{HASIL}

\section{Karakteristik Remaja}

Usia remaja dalam penelitian ini berkisar antara 15-18 tahun. Selain itu, hampir tujuh dari delapan remaja $(87,5 \%)$ rata-rata berusia 16 tahun, baik laki-laki maupun perempuan. Dalam penelitian ini ditemukan bahwa remaja memiliki urutan kelahiran dimulai dari anak pertama hingga anak ketujuh. Berdasarkan total responden, lebih dari empat per sepuluh $(41,7 \%)$ remaja merupakan anak pertama. Selain itu, lebih dari empat per sepuluh (44,2\%) remaja laki-laki dan lebih dari sepertiga $(39,2 \%)$ remaja perempuan adalah anak pertama.

\section{Karakteristik Keluarga}

Rentang usia ibu secara keseluruhan pada penelitian ini antara 32-63 tahun sedangkan rentang usia ayah antara 30-71 tahun.

Tabel 1 Sebaran remaja berdasarkan kategori dimensi keberfungsian agama di keluarga

\begin{tabular}{lccccc}
\hline & \multicolumn{3}{c}{ Kategori (\%) } & Min- & Rata- \\
\cline { 2 - 5 } Dimensi & $\begin{array}{c}\text { Rendah } \\
(00,0-\end{array}$ & $\begin{array}{c}\text { Sedang } \\
(60,0-\end{array}$ & $\begin{array}{c}\text { Tinggi } \\
(80,0-\end{array}$ & $\begin{array}{c}\text { Max } \\
\text { rata }\end{array}$ \\
& $60,0)$ & $79,0)$ & $100,0)$ & & SD \\
\hline $\begin{array}{l}\text { Keiman- } \\
\text { an }\end{array}$ & 2,1 & 13,7 & 84,2 & 41,7 & 68,5 \\
& & & & -100 & \pm \\
Pengeta & 10,0 & 34,4 & 55,6 & 20,0 & 48,2 \\
-huan & & & & -100 & \pm \\
& & & & & 13,5 \\
Pengala & 0,4 & 14,9 & 84,6 & 40,0 & 77,7 \\
-man & & & & -100 & \pm \\
& & & & & 11,5 \\
Ritual & 2,1 & 15,8 & 82,1 & 46,7 & 44,4 \\
& & & & -100 & \pm \\
& & & & & 15,2 \\
Konse- & 47,3 & 38,6 & 14,1 & $5,6-$ & 73,0 \\
kuensi & & & & 100 & \pm \\
& & & & & 16,1 \\
\hline Total & 3,8 & 37,5 & 58,8 & 48,0 & 80,7 \\
& & & & - & \pm \\
& & & & 98,7 & 10,7 \\
\hline
\end{tabular}


Sementara itu, hampir tiga per empat $(71,2 \%)$ remaja memiliki ibu dengan kategori usia madya (41-60 tahun) dan lebih dari seperempat $(27,9 \%)$ dengan kategori dewasa awal (18-40 tahun) dengan rata-rata usia seluruh ibu 44.56 tahun. Sementara itu, sebagian besar $(91,7 \%)$ ayah berusia dewasa madya (41-60 tahun) dan rata-rata usia ayah adalah 48,57 tahun. Berdasarkan pendidikan ibu, hampir setengah ibu $(47,5 \%)$ berpendidikan SMA dan sisanya berpendidikan S1 $(23,3 \%)$, berpendidikan SD $(12,1 \%)$, berpendidikan SMP $(12,5 \%)$, dan berpendidikan S2 (4,6\%). Rata-rata pendidikan ibu adalah 11,87 tahun atau setara lulusan SMA. Sementara itu, lebih dari setengah $(61,3 \%)$ ayah mempunyai lama pendidikan pada rentang 13-16 tahun atau D3 dan S1, dengan rata-rata lama pendidikan ayah selama 14,2 tahun atau setara dengan perguruan tinggi.

\section{Keberfungsian Agama di Keluarga}

Tabel 1 menjelaskan bahwa lebih dari setengah $(58,8 \%)$ orang tua melakukan keberfungsian agama di keluarga dengan baik dengan terkategori tinggi, lebih dari sepertiga $(37,5 \%)$ terkategori sedang, dan sisanya $(3,8 \%)$ terkategori rendah. Jika dilihat per dimensi, empat dari lima dimensi keberfungsian agama di keluarga berada pada kategori tinggi yaitu dimensi keyakinan $(84,2 \%)$, pengetahuan $(55,6 \%)$, pengalaman $(84,6 \%)$, dan praktek ibadah (82,1\%). Sementara itu, dimensi konsekuensi berada pada kategori rendah $(47,3 \%)$

Keimanan. Tabel 1 menunjukkan sebanyak 84,2 persen remaja mempunyai keluarga dengan kategori tinggi pada keimanan.

Tabel 2 Sebaran responden berdasarkan kategori dimensi interaksi teman sebaya

\begin{tabular}{|c|c|c|c|c|c|}
\hline \multirow[b]{2}{*}{ Dimensi } & \multicolumn{3}{|c|}{ Kategori (\%) } & \multirow[b]{2}{*}{$\begin{array}{l}\text { Min- } \\
\text { Max }\end{array}$} & \multirow[b]{2}{*}{$\begin{array}{c}\text { Rata- } \\
\text { rata } \\
\text { SD }\end{array}$} \\
\hline & $\begin{array}{c}\text { Rendah } \\
(00,0- \\
60,0)\end{array}$ & $\begin{array}{c}\text { Sedang } \\
(60,0- \\
79,0)\end{array}$ & $\begin{array}{l}\text { Tinggi } \\
(80,0- \\
100,0)\end{array}$ & & \\
\hline $\begin{array}{l}\text { Persahabat } \\
\text {-an }\end{array}$ & 56,0 & 29,5 & 14,5 & $\begin{array}{l}0,0- \\
100\end{array}$ & $\begin{array}{c}34,5 \pm \\
18,9\end{array}$ \\
\hline Konflik & 42,1 & 33,3 & 24,6 & $\begin{array}{l}0,0- \\
100\end{array}$ & $\begin{array}{c}65,4 \pm \\
18,3\end{array}$ \\
\hline Bantuan & 47,7 & 32,0 & 20,3 & $\begin{array}{l}0,0- \\
100\end{array}$ & $\begin{array}{c}59,1 \pm \\
17,8\end{array}$ \\
\hline Kedekatan & 49,8 & 32,4 & 17,8 & $\begin{array}{l}6,7- \\
100\end{array}$ & $\begin{array}{c}57,7 \pm \\
17,8\end{array}$ \\
\hline Rasa Aman & 92,9 & 4,6 & 2,5 & $\begin{array}{l}0,0- \\
100\end{array}$ & $\begin{array}{c}30,2 \\
\pm \\
16,7\end{array}$ \\
\hline Total & 52,5 & 47,1 & 0,4 & $\begin{array}{l}23,2- \\
88,4\end{array}$ & $\begin{array}{c}59,8 \\
\pm \\
9,6\end{array}$ \\
\hline
\end{tabular}

Hal tersebut ditunjukkan dengan keluarga selalu mengajarkan anak untuk percaya bahwa Tuhan akan menambah rezeki orang yang mau berbagi.

Pengetahuan. Penelitian memperlihatkan bahwa lebih dari setengah $(55,6 \%)$ remaja mempunyai keluarga dengan kategori tinggi untuk dimensi pengetahuan. Hal ini didukung dengan mengajarkan anak untuk meneladani sikap para Nabi yang memberi tanpa pamrih dan bersikap lembut.

Pengalaman. Hasil menggambarkan bahwa lebih dari tiga per empat $(84,6 \%)$ remaja mempunyai keluarga dengan dimensi pengalaman yang tinggi dalam keberfungsian agama, seperti membiasakan anak untuk berdo'a dan menyerahkan segala urusan kepada Tuhan.

Ritual. Penelitian ini menunjukkan bahwa dimensi ritual dalam keberfungsian agama di dalam keluarga berada pada kategori tinggi $(82,1 \%)$. Hal ini terutama terlihat dalam mengajarkan anak untuk melaksanakan ibadah ritual sholat 5 waktu setiap hari.

Konsekuensi. Hasil penelitian ini menunjukkan bahwa hampir setengah $(47,3 \%)$ remaja mempunyai keluarga dengan dimensi konsekuensi rendah. Hal ini dapat dilihat pada terdapat 27,9 persen ibu tidak mengajak anak ke tempat duka, agar anak mengerti cara berempati kepada sesama.

\section{Ancaman}

Hasil penelitian menunjukkan bahwa hampir seluruh remaja $(91,8 \%)$ laki-laki dan perempuan berada pada tingkat ancaman yang rendah dari teman sebaya.

Tabel 3 Sebaran responden berdasarkan kategori dimensi religiusitas remaja

\begin{tabular}{|c|c|c|c|c|c|}
\hline \multirow[b]{2}{*}{ Dimensi } & \multicolumn{3}{|c|}{ Kategori (\%) } & \multirow[b]{2}{*}{$\begin{array}{l}\text { Min- } \\
\text { Max }\end{array}$} & \multirow[b]{2}{*}{$\begin{array}{c}\text { Rata- } \\
\text { rata } \pm \\
\text { SD }\end{array}$} \\
\hline & $\begin{array}{c}\text { Rendah } \\
(00,0- \\
60,0)\end{array}$ & $\begin{array}{c}\text { Sedang } \\
(60,0- \\
79,0)\end{array}$ & $\begin{array}{l}\text { Tinggi } \\
(80,0- \\
100,0)\end{array}$ & & \\
\hline Keyakinan & 2,1 & 87,6 & 10,4 & $\begin{array}{l}33,3- \\
100\end{array}$ & $\begin{array}{c}68,5 \pm \\
7,6\end{array}$ \\
\hline Ritual & 78,0 & 17,8 & 4,2 & $\begin{array}{c}20,0- \\
100\end{array}$ & $\begin{array}{c}48,2 \pm \\
13,5\end{array}$ \\
\hline Pengalaman & 2,9 & 37,3 & 59,7 & $\begin{array}{c}40,0- \\
100\end{array}$ & $\begin{array}{c}77,7 \pm \\
11,5\end{array}$ \\
\hline Konsekwensi & 86,3 & 9,1 & 4,5 & $\begin{array}{c}16,7- \\
100\end{array}$ & $\begin{array}{c}44,4 \pm \\
15,2\end{array}$ \\
\hline $\begin{array}{l}\text { Pengetahuan } \\
\text { Agama }\end{array}$ & 6,2 & 58,1 & 35,7 & $\begin{array}{l}0,0- \\
100\end{array}$ & $\begin{array}{c}73,0 \pm \\
16,1 \\
\end{array}$ \\
\hline Total & 38,5 & 58,2 & 3,3 & $\begin{array}{c}36,9- \\
100\end{array}$ & $\begin{array}{c}62,3 \pm \\
8,4 \\
\end{array}$ \\
\hline
\end{tabular}


Tabel 4 Hasil analisis uji beda variabel keberfungsian agama, ancaman, interaksi teman sebaya, dan religiusitas remaja

\begin{tabular}{|c|c|c|c|c|c|c|c|c|c|}
\hline \multirow{2}{*}{ Pernyataan } & \multicolumn{3}{|c|}{ Jenis Kelamin } & \multicolumn{3}{|c|}{ Jenis Sekolah } & \multicolumn{3}{|c|}{ Status Sekolah } \\
\hline & Lk & $\operatorname{Pr}$ & P-Value & SMK & SMA & P-Value & Negeri & Swasta & P-Value \\
\hline Keberfungsian & 7807 & 809 & 0,206 & 817 & & $0,000^{\star *}$ & 806 & 807 & 0,106 \\
\hline $\begin{array}{l}\text { Agama } \\
\text { - Keimanan }\end{array}$ & $\begin{array}{l}80,1 \\
90,8\end{array}$ & $\begin{array}{l}89,9 \\
92,2\end{array}$ & 0.391 & 91,0 & 91,9 & 0.233 & 90.6 & 92,4 & 0,213 \\
\hline - Pengetahuan & 78,0 & 80,5 & 0,254 & 80,5 & 77,9 & 0,942 & 77,9 & 80,6 & 0,275 \\
\hline - Pengalaman & 89,8 & 93,0 & $0,041^{*}$ & 91,4 & 91,3 & 0,586 & 90,5 & 92,2 & $0,034^{*}$ \\
\hline - Ritual & 86,6 & 93,0 & $0,014^{*}$ & 89,0 & 88,1 & $0,000^{* *}$ & 86,8 & 90,3 & 0,497 \\
\hline - Konsekwensi & 58,5 & 90,6 & 0,521 & 71,7 & 43,6 & 0,607 & 57,2 & 58,0 & 0,264 \\
\hline Ancaman & 9,5 & 5,3 & $0,000^{* *}$ & 6,7 & 6,3 & 0,958 & 6,6 & 6,5 & 0,793 \\
\hline Interaksi Teman & & & 0,434 & & & 0,894 & & & $0,000^{* *}$ \\
\hline Sebaya & 53,7 & 55,9 & & 54,9 & 55,4 & & 53,7 & 55,9 & \\
\hline - Persahabatan & 61,7 & 60,9 & 0,710 & 61,6 & 60,9 & 0,756 & 59,5 & 63,1 & 0,106 \\
\hline - Konflik & 63,1 & 67,9 & $0,047^{*}$ & 65,8 & 65,2 & 0,777 & 68,6 & 62,4 & $0,010^{*}$ \\
\hline - Bantuan & 57,4 & 60,9 & 0,129 & 58,4 & 63,9 & 0,548 & 57,6 & 60,7 & 0,170 \\
\hline - Kedekatan & 54,7 & 60,8 & $0,008^{\star *}$ & 58,1 & 57,3 & 0,736 & 56,6 & 58,9 & 0,312 \\
\hline $\begin{array}{l}\text { - Rasa Aman } \\
\text { Religiusitas }\end{array}$ & 31,7 & 28,8 & 0,181 & 30,5 & 29,9 & 0,758 & 26,3 & 34,2 & $0,000^{* *}$ \\
\hline Remaja & 63,9 & 60,9 & $0,000^{* *}$ & 63,5 & 61,3 & $0,040^{* *}$ & 55,5 & 63,9 & $0,004^{\star *}$ \\
\hline - Keimanan & 69,5 & 67,5 & $0,034^{*}$ & 69,4 & 67,6 & 0,066 & 67,4 & 69,6 & $0,021^{*}$ \\
\hline - Pengetahuan & 74,3 & 71,7 & 0,212 & 74,6 & 71,5 & 0,141 & 43,5 & 75,8 & $0,007^{*}$ \\
\hline - Pengalaman & 77,8 & 77,7 & 0,940 & 79,0 & 76,5 & 0,084 & 75,7 & 79,7 & $0,007^{*}$ \\
\hline - Ritual & 49,9 & 46,5 & 0,051 & 49,2 & 47,2 & 0,238 & 47,3 & 49,1 & 0,292 \\
\hline - Konsekuensi & 47,8 & 41,0 & $0,000^{*}$ & 45,3 & 43,5 & 0,370 & 43,5 & 45,3 & 0,370 \\
\hline
\end{tabular}

Keterangan :

Lk: laki-laki, Pr : perempuan, SMA: sekolah menengah atas, SMK: sekolah menengah kejuruan

Rendahnya ancaman terlihat pada remaja tidak diajak merokok, tidak dipaksa membolos, minum-minuman keras, menggunakan narkoba, tawuran, dan tidak diajak seks bebas. Meskipun begitu, beberapa ancaman seperti dipaksa merokok, seks bebas, dan pernah dijauhi teman muncul pada remaja dalam penelitian ini walaupun tingkat persentase terhitung rendah $(8,2 \%)$.

\section{Interaksi Teman Sebaya}

Hasil penelitian menunjukkan bahwa lebih dari setengah remaja $(52,5 \%)$ memiliki interaksi yang rendah dengan teman sebayanya. Sementara itu, kurang dari setengah remaja $(47,1 \%)$ terkategori sedang dan sisanya $(0,4 \%)$ terkategori tinggi.

Persahabatan. Penelitian menemukan bahwa lebih dari setengah $(56,0 \%)$ remaja termemiliki persahabatan dengan kategori rendah, lebih dari seperempat $(29,5 \%)$ terkategori sedang dan sisanya $(14,5 \%)$ terkategori tinggi.

Konflik. Penelitian memperlihatkan kurang dari setengah $(42,1 \%)$ remaja memiliki konflik yang rendah, sepertiganya $(33,3 \%)$ memiliki konflik yang sedang dan hampeir seperempat $(24,6 \%)$ remaja berada pada tingkat konflik yang tinggi.

Bantuan. Bantuan yang diberikan antarteman masih tergolong rendah $(47,7 \%)$, hampir sepertiga $(32,0 \%)$ tergolong sedang, dan sisanya $(20,3 \%)$ tergolong tinggi

Kedekatan. Hasil penelitian menunjukkan bahwa hampir setengah $(49,8 \%)$ remaja memiliki kedekatan yang rendah dengan teman sebaya. Selain itu, hampir sepertiga remaja $(32,4 \%)$ terkategori sedang dan sisanya $(17,8 \%)$ terkategori tinggi.,

Rasa Aman. Penelitian juga menemukan bahwa hampir semua remaja $(92,9 \%)$ kurang merasa aman dengan teman sebayanya. Penelitian ini hanya menemukan remaja sebesar $4,6 \%$ yang terkategori sedang dan $2,5 \%$ terkategori tinggi.

\section{Religiusitas Remaja}

Religiusitas merupakan satu unsur penting yang dibutuhkankan oleh remaja karena religiusitas merupakan penunjang resiliensi. Hasil penelitian menemukan bahwa lebih dari setengah remaja $(58,2 \%)$ memiliki religiusitas dengan kategori sedang, lebih dari sepertiga $(38,5 \%)$ terkategori rendah, dan sisanya $(3,3 \%)$ terkategori tinggi (Tabel 3 ).

Keyakinan. Hasil penelitian menemukan bahwa lebih dari dua per tiga $(87,6 \%)$ remaja memiliki keyakinan dengan kategori sedang. Sementara itu, hanya sepersepuluh $(10,4 \%)$ 
yang terkategori tinggi dan sisanya terkategori rendah.

Ritual. Penelitian juga menemukan bahwa lebih dari tiga per empat $(78,8 \%)$ dimensi ritual termasuk dalam kategori rendah dan hampir seperlima $(17,8 \%)$ terkategori sedang; sisanya $(2,1 \%)$ terkategori tinggi.

Pengalaman. Data yang tersaji pada Tabel 3 juga menunjukkan bahwa lebih dari setengah lebih $(59,7 \%)$ remaja berada pada kategori tinggi dalam hal pengalaman terkait religiusitas. Selain itu, sepertiga lebih remaja $(37,3 \%)$ pada kategori sedang dan sisanya $(2,9 \%)$ terkategori rendah.

Konsekuensi. Konsekuensi pada religiusitas relatif rendah mengingat proporsi tertinggi remaja $(86,3 \%)$ berada pada kategori rendah. Selain itu, hampir sepersepuluh $(9,1 \%)$ remaja terkategori sedang dan sisanya (4,5\%) terkategori tinggi.

Pengetahuan agama. Hasil penelitian menemukan bahwa sebanyak $58,1 \%$ remaja berada pada kategori sedang, sepertiganya $(35.7 \%)$ terkategori tinggi, dan sisanya $(6,2 \%)$ terkategori rendah.

\section{Perbedaan Keberfungsian Agama, Ancaman, Interaksi Teman Sebaya, dan Religiusitas Remaja berdasarkan Jenis Kelamin, Jenis Sekolah, Status Sekolah}

Tabel 4 menjelaskan bahwa orang tua dari remaja siswa SMK menjalankan keberfungsian agama di keluarga lebih baik daripada orang tua remaja siswa SMA. Sementara itu, pada dimensi praktek ibadah, orang tua dari remaja perempuan menjalankan keberfungsian praktek ibadah lebih baik daripada orang tua remaja laki-laki dengan $p$-value 0,014 . Orang tua dari remaja siswa SMK menjalankan keberfungsian praktek ibadah lebih baik dibandingkan orang tua dari remaja siswa SMA $(0,000)$. Pada dimensi pengalaman, orang tua dari remaja perempuan melakukan keberfungsian lebih baik dari orang tua remaja laki-laki dengan $p$-value 0,041 dan orang tua dari remaja siswa sekolah swasta menjalankan keberfungsian lebih baik dibandingkan orang tua dari remaja siswa sekolah negeri dengan nilai $p$-value 0,034 . Hasil penelitian menunjukkan adanya perbedaan yang nyata antara ancaman yang dirasakan remaja lakilaki dan perempuan dengan nilai $p$-value sebesar 0,000 yang menunjukkan bahwa remaja laki-laki menghadapi ancaman yang lebih besar dibandingkan remaja perempuan.
Namun, tidak ditemukan perbedaan ancaman yang dirasakan remaja siswa SMK maupun SMA dan siswa sekolah negeri maupun sekolah swasta.

Penelitian ini juga menemukan bahwa remaja siswa sekolah swasta berinteraksi lebih baik dengan teman sebaya dibandingkan dengan remaja siswa sekolah swasta. Remaja laki-laki mengalami konflik yang lebih tinggi dibandingkan remaja perempuan dengan nilai $p$-value 0,047, Sebaliknya, remaja perempuan memiliki tingkat kedekatan dengan teman sebaya lebih tinggi dibandingkan remaja lakilaki dengan nilai p-value sebesar 0,008. Berdasarkan status sekolah, terdapat perbedaan pada remaja siswa sekolah negeri dan swasta dalam dimensi konflik dan rasa aman. Berdasarkan capaian rata-rata, remaja siswa sekolah swasta memiliki konflik yang lebih tinggi dibandingkan remaja siswa sekolah negeri dengan nilai $p$-value 0,010 sedangkan pada dimensi rasa aman remaja siswa sekolah swasta lebih merasa aman bersama temannya dibandingkan remaja siswa sekolah negeri dengan nilai $p$-value 0,000 .

Selanjutnya, penelitian ini menemukan bahwa remaja laki-laki memiliki tingkat religiusitas lebih tinggi dibandingkan remaja perempuan dengan nilai $p$-value 0,000 . Remaja siswa SMK memiliki tingkat religiusitas yang lebih tinggi daripada remaja siswa SMA dengan nilai $p$-value 0,040.

Tabel 5 Koefisien regresi karakteristik, keberfungsian agama di keluarga, ancaman, dan interaksi teman sebaya terhadap religiusitas remaja

\begin{tabular}{|c|c|c|c|}
\hline \multirow{2}{*}{ Variabel } & \multicolumn{3}{|c|}{ Koefisien } \\
\hline & $(\mathrm{B})$ & $(\beta)$ & Sig \\
\hline (Constant) & 14,528 & & 0,661 \\
\hline Usia anak & 2,344 & 0,111 & $0,037^{*}$ \\
\hline $\begin{array}{l}\text { Jenis kelamin } \\
(0=\text { laki-laki, } \\
1=\text { perempuan })\end{array}$ & $-4,211$ & $-0,249$ & $0,000^{* *}$ \\
\hline $\begin{array}{l}\text { Jenis pendidikan } \\
(0=S M K, 1=S M A)\end{array}$ & $-1,283$ & $-0,076$ & 0,268 \\
\hline $\begin{array}{l}\text { Status sekolah } \\
(0=\text { Negeri, } \\
1=\text { SWasta })\end{array}$ & 1,806 & 0,107 & $0,006^{* *}$ \\
\hline Usia ibu & $-0,167$ & $-0,114$ & 0,117 \\
\hline Pendidikan ibu & 0,184 & 0,069 & 0,655 \\
\hline $\begin{array}{l}\text { Keberfungsian } \\
\text { agama }\end{array}$ & 0,119 & 0,150 & $0,017^{*}$ \\
\hline Ancaman & $-0,129$ & $-0,143$ & 0,069 \\
\hline $\begin{array}{l}\text { Interaksi teman } \\
\text { sebaya }\end{array}$ & 0,262 & 0,348 & $0,007^{* *}$ \\
\hline Uji F & & 5,532 & \\
\hline Adjusted $R$ Square & & 0,159 & \\
\hline Sig & & $0,000^{* *}$ & \\
\hline
\end{tabular}


Sementara pada remaja siswa sekolah swasta memiliki tingkat religiusitas yang lebih tinggi daripada remaja siswa sekolah negeri dengan nilai $p$-value 0,004. Berdasarkan dimensi, pada dimensi keyakinan, remaja laki-laki memiliki keyakinan yang lebih tinggi dibandingkan remaja perempuan dengan nilai $p$-value 0,034 dan pada dimensi konsekuensi remaja laki-laki lebih tinggi dibandingkan remaja perempuan dengan nilai $p$-value 0,000. Remaja siswa sekolah swasta memiliki keyakinan dengan nilai $p$-value 0,021 , pengalaman dengan nilai $p$ value 0,007 , dan pengetahuan $(0,007)$ yang lebih tinggi dibandingkan remaja siswa sekolah negeri.

\section{Pengaruh Karakteristik, Keberfungsian Agama di Keluarga, Ancaman, dan Interaksi Teman Sebaya Terhadap Religiusitas Remaja}

Tabel 5 menunjukan bahwa berdasarkan hasil analisis regresi linier variabel-variabel terhadap religiusitas remaja, angka Adjusted $R$ Square yang diperoleh adalah 0,159 yang berarti 15,9 persen variabel-variabel tersebut memengaruhi religiusitas remaja dan sisanya 84,1 persen dipengaruhi variabel lain di luar model. Usia remaja berpengaruh positif terhadap religiusitasnya $(\beta=2,344)$ yang menunjukkan bahwa peningkatan usia remaja menyebabkan peningkatan religiusitasnya. Jenis kelamin berpengaruh negatif terhadap religiusitas remaja $(\beta=-4,211)$, remaja laki-laki memiliki tingkat religiusitas yang lebih tinggi dibandingkan remaja perempuan. Sementara itu, internalisasi keberfungsian agama $(\beta=$ $0,119)$ berpengaruh positif terhadap religiusitas remaja. Hal tersbeut menunjukkan bahwa setiap kenaikan satu satuan internalisasi keberfungsian agama maka akan menaikkan religiusitas remaja sebesar 0,017 poin. Interaksi teman sebaya $(\beta=0,262)$ berpengaruh positif terhadap religiusitas remaja yang berarti bahwa setiap kenaikan satu satuan interaksi maka akan menaikkan religiusitas remaja sebesar 0,007 poin. Hal tersebut menunjukkan bahwa remaja yang semakin baik persahabatan, bantuan, rasa aman, dan kedekatan dengan teman sebayanya maka menyebabkan peningkatan religiusitasnya.

\section{PEMBAHASAN}

Penelitian ini menggunakan teori struktural fungsional dan teori ekologi keluarga sebagai perspektif teori dalam membangun variabelvariabel dan hubungan antarvariabel. Kedua teori menjelaskan bahwa keluarga memiliki struktur yang berdampak pada adanya peran pada masing-masing anggota keluarga. Hasil penelitian menunjukkan bahwa orang tua telah melakukan keberfungsian agama di keluarga dengan baik. Keberfungsian agama ini ditunjukkan dengan orang tua telah mengajarkan anak untuk percaya bahwa Tuhan selalu mengawasi, membiasakan anak untuk membaca buku-buku cerita tentang sikap jujur, membiasakan anak untuk jujur, dan mengajarkan anak untuk melaksanakan ibadah ritual sholat lima waktu setiap hari. Keberfungsian agama yang ditemukan dalam penelitian ini sejalan dengan Petts (2014) yang mengemukakan bahwa keluarga merupakan tempat sosialisasi pertama dalam memperkenalkan agama kepada anak.

Penelitian memperlihatkan bahwa hampir semua remaja tidak menghadapi faktor ancaman, namun bukan berarti bahwa ancaman itu tidak ada. Beberapa ancaman yang dihadapi remaja diantaranya diajak dan dipaksa merokok, dipaksa seks bebas, dan dijauhi teman meskipun dalam proporsi yang sangat kecil. Persentase yang rendah pada ancaman, tidak dapat dinilai sebagai situasi yang aman karena satu perilaku negatif yang dilakukan remaja akan meninggalkan jejak yang buruk dan mengganggu perkembangannya. Hasil penelitian juga menggambarkan remaja laki-laki menghadapi ancaman yang lebih besar daripada remaja perempuan. Hal ini selaras dengan hasil penelitian Sunarti et al. (2017) yang menyatakan bahwa remaja laki-laki lebih banyak dihadapkan pada ancaman dibandingkan dengan remaja perempuan. Sejumlah penelitian menegaskan bahwa remaja perempuan memiliki tingkat kontrol diri yang lebih tinggi daripada remaja laki-laki (Botchcovar et al., 2016). Remaja laki-laki yang cenderung memiliki fisik lebih kuat dari perempuan memungkinkannya lebih berani mencoba hal-hal yang dianggap berbahaya. Dibandingkan dengan remaja laki-laki, remaja perempuan lebih banyak berbagi dukungan/persetujuan, pertanyaan, pengalaman, informasi, dan pengakuan (Rose et al., 2016). Selain itu, kemampuan remaja menghadapi ancaman dipengaruhi oleh perhatian orang tua. Fergus dan Zimmerman (2005); Zolkoski dan Bullock (2012) menyatakan bahwa faktor-faktor yang mendorong terjadinya ancaman bagi anak adalah penganiayaan, kekerasan, pelecehan, dan kurangnya perhatian dari orangtua. Masa remaja merupakan masa penemuan jati diri dan pada saat-saat seperti itu biasanya remaja bertingkah sembarangan tanpa memikirkan akibat yang akan terjadi dari perbuatannya 
(Santrock, 2007). Keingintahuan yang besar pada remaja, pengaruh negatif media dan lingkungan bermain, kondisi keluarga yang kurang kondusif (orang tua sibuk bekerja, pola asuh yang tidak tepat, kondisi keluarga yang tidak harmonis) menjadi faktor yang berpengaruh terhadap penyimpangan pada masa remaja (Widianti, 2011). Apabila remaja berada pada lingkungan sekolah dan rumah yang kondusif dan aman maka berbagai ancaman dapat dicegah dan dihindarinya. Rendahnya interaksi remaja dengan teman sebaya dapat disebabkan karena perubahan pubertas yang berkaitan dengan meningkatnya emosi-emosi negatif (Santrock, 2007). Remaja memilih untuk menghindari interaksi dengan teman sebaya karena kekhawatiran akan terjadinya konflik. Situasi emosi yang fluktuatif berpotensi memicu masalah tidak hanya dengan teman sebaya tetapi juga dengan orang dewasa.

Penelitian ini juga menunjukan bahwa remaja siswa sekolah swasta melakukan interaksi dengan teman sebaya lebih tinggi daripada remaja di sekolah negeri. Kondisi ini ditunjukkan dengan remaja siswa sekolah swasta lebih tinggi rasa persahabatannya dibandingkan siswa sekolah negeri. Remaja mulai mengenal dan berinteraksi dengan lingkungan di luar rumah selain keluarga seperti dengan teman sebayanya. Proses interaksi membentuk anak menjadi pribadi yang lebih baik atau sebaliknya tergantung fondasi yang diterapkan keluarga (Mukama, 2010). Bronfenbrenner dalam teori ekologinya menyebutkan bahwa keluarga dan lingkungan teman sebaya merupakan kelompok yang berada pada lingkungan mikro yaitu lingkungan dekat yang berinteraksi langsung dengan individu dan berpengaruh besar terhadap perkembangan seorang anak. Penelitian ini juga menjadikan jenis sekolah sebagai salah satu hal yang dianalisis, yaitu antara SMK dan SMA. SMK mempunyai karakteristik yang berbeda dari sekolah umum yaitu terdapat mata pelajaran produktif atau praktik. Pembelajaran di SMK sebesar 70 persen diisi dengan praktik dan hanya 30 persen teori, dikarenakan lulusan SMK dituntut memiliki keahlian tertentu (Zahra, Suherman, \& Permana, 2017). Remaja SMK yang sering melakukan praktik memungkinkan lebih banyak interaksi dengan teman sebaya melalui komunikasi karena kebutuhan untuk saling membantu dan bekerja sama sebagaimana yang didapati di lapangan saat penelitian ini dilakukan.

Sementara itu, religiusitas remaja berada pada tingkat sedang dan remaja laki-laki memiliki tingkat religiusitas lebih tinggi dibandingkan remaja perempuan. Menurut Bryant (2007), identitas keagamaan lebih berpengaruh kuat terhadap spiritualitas laki-laki dibandingkan spiritualitas perempuan. Remaja siswa SMK memiliki religiusitas yang lebih tinggi dibandingkan siswa SMA. Hal ini sesuai dengan hasil penelitian ini pada variabel keberfungsian agama yang menunjukan bahwa orang tua siswa SMK melakukan keberfungsian agama lebih tinggi daripada siswa SMA. Remaja siswa sekolah swasta memiliki religiusitas yang lebih tinggi dibandingkan remaja siswa sekolah negeri. Sekolah swasta memiliki keleluasaan yang lebih besar untuk melakukan modifikasi sistem pembelajaran termasuk mengatur waktu untuk melakukan kegiatan-kegiatan ekstra diantaranya kegiatan agama. Namun dalam hal prestasi, hasil ini berbeda dengan hasil penelitian sebelumnya yang dilakukan oleh Sayidani, Irianto, dan Fuady (2016) yang menyatakan bahwa tidak terdapat perbedan prestasi antara mahasiswa yang berasal dari SMK dan SMA.

Uji pengaruh pada penelitian ini menunjukan bahwa remaja laki-laki memiliki tingkat religiusitas yang lebih tinggi dibandingkan perempuan. Hal ini sejalan dengan penelitian sebelumnya oleh kecerdasan spiritual ibu dengan anak laki-laki lebih baik dibandingkan ibu dengan anak perempuan (Puspitasari, Hastuti, \& Herawati, 2016). Penelitian Tasqiya, Hastuti, dan Puspitawati (2018) juga memperlihatkan bahwa remaja laki-laki memiliki kecerdasan spiritual yang lebih tinggi daripada remaja perempuan. Identitas keagamaan memiliki pengaruh pada spiritualitas seseorang. Lebih lanjut, identitas keagamaan lebih berpengaruh kuat terhadap spiritualitas laki-laki dibandingkan spiritualitas perempuan (Bryant, 2007). Laki-laki muslim lebih sering dan lebih teratur menghadiri acaraacara keagamaan daripada wanita Muslim sesuai dengan norma-norma Islam (Hackett, Murphy, \& McClendon, 2016). Namun, hal ini bertentangan dengan penelitian terdahulu yang menyebutkan bahwa kecerdasan spiritual perempuan umumnya lebih tinggi daripada lakilaki (Bliss \& Ekmark, 2013). Secara umum, remaja perempuan menilai diri mereka memiliki tingkat religiusitas lebih tinggi daripada laki-laki dan hal ini menunjukkan bahwa perempuan lebih sensitif secara rohani daripada laki-laki (Kirsi, Nokelainen, \& Ubani, 2006).

Penelitian ini juga menemukan bahwa semakin tinggi keberfungsian agama di keluarga semakin tinggi religiusitas remaja. Keluarga yang memiliki keberfungsian agama yang 
optimal maka akan dapat meningkatkan religiusitas remaja. Religiusitas orang tua merupakan modal dasar dan utama dalam mendidik dan berinteraksi dengan remaja. Aktivitas orang tua dalam keluarga untuk menanamkan nilai-nilai religius pada remaja disebut dengan keberfungsian agama dalam keluarga (Smith \& Denton, 2005). Menurut Vermeer (2014), peran orang tua menjadi hal yang penting dalam upaya penanaman nilai agama di keluarga. Orang tua yang mampu melakukan internalisasi keberfungsian agama dengan baik dapat meningkatkan perubahan positif pada anak karena mengikuti jejak orang tua mereka secara utuh dalam beragama. Orang tua adalah model peran iman dan dapat membentuk perkembangan religius anak-anak melalui dialog atau pengajaran (Schwartz, 2006). Proses pengamatan dan peniruan juga berlaku pada sosialiasi agama dalam keluarga, anak mengamati dan meniru tindakan religius orang tua (King \& Mueller, 2003). Kecerdasan spiritual dapat dipelajari dari keluarga sebagai lingkungan pertama dan utama individu melalui interaksi orang tua dengan anak dalam bentuk pengasuhan (Najam \& Batool, 2012).

Hasil lain dalam penelitian ini adalah ditemukannya bahwa semakin tinggi interaksi remaja dengan teman sebaya semakin tinggi religiusitas remaja. Hal ini berarti jika remaja memiliki interaksi yang baik dengan teman sebayanya dan melakukan kegiatan positif atau kegiatan keagamaan bersama-sama, maka tingkat religiusitas remaja akan meningkat. Desrotser et al. (2011) membuktikan adanya pengaruh positif dari orang tua dan teman sebaya terhadap kecerdasan spiritual remaja. Menurut Najam dan Batool (2012) menyebutkan bahwa remaja perlu dibekali dengan kecerdasan spiritual mengingat peran pentingnya sebagai generasi penerus bangsa. Kecerdasan spiritual dapat dipelajari dari keluarga sebagai lingkungan pertama dan utama individu melalui interaksi orang tua dengan anak dalam bentuk pengasuhan. Kecerdasan spiritual berkaitan erat dengan konsep dan pandangan anak tentang Tuhan yang dipengaruhi oleh pengasuhan orang tua. Spiritualitas yang dimiliki teman sebaya berpengaruh positif terhadap religiusitas remaja. Praktek spiritual dan keagamaan dapat mempromosikan hubungan interpersonal anakanak dan dukungan sosial yang terkait dengan kesejahteraan mereka (Holder et al., 2015). Proses interaksi dengan teman sebaya dapat merubah banyak hal yang terjadi dalam kehidupan seseorang termasuk perilaku (Walker, Hennig, \& Kretteneur, 2000). Keberfungsian agama yang baik dalam keluarga dan didukung interaksi yang positif dengan teman sebaya akan meningkatkan religiusitas remaja sehingga diharapkan remaja mampu menghadapi berbagai masalah khususnya tekanan yang dihadapi dalam kehidupannya.

\section{SIMPULAN DAN SARAN}

Hasil penelitian menunjukkan rata-rata usia remaja dalam penelitian ini adalah 16 tahun dan rata-rata usia ibu 44,5 tahun. Rata-rata pendidikan ibu setara lulusan SMA. Keberfungsian agama di keluarga terkategori tinggi, ancaman yang dihadapi remaja terkategori rendah, interaksi dengan teman sebaya terkategori rendah, dan religiusitas remaja terkategori sedang. Uji pengaruh yang dilakukan menunjukkan bahwa usia remaja, keberfungsian agama dan interaksi teman sebaya berpengaruh positif terhadap religiusitas remaja. Hasil penelitian menunjukkan bahwa peningkatan usia remaja, keberfungsian agama, dan interaksi teman sebaya akan menyebabkan peningkatan religiusitas remaja Jenis kelamin berpengaruh negatif terhadap religiusitas remaja yang mana remaja laki-laki memiliki peluang tingkat religiusitas yang lebih tinggi dibandingkan remaja perempuan.

Berdasarkan hasil penelitian maka remaja disarankan untuk meningkatkan keterampilan menghadapi ancaman terutama remaja lakilaki. Orang tua disarankan untuk meningkatkan keberfungsian agama di keluarga dengan mengajak remaja hadir pada undangan tetangga dan membantu tetangga yang sedang berduka. Orang tua juga disarankan melakukan pendampingan dan pengawasan pada remaja dalam menghadapi ancaman yang mereka hadapinya. Sementara itu, guru disarankan lebih banyak memberikan pengertian dan gambaran resiko yang akan ditanggung remaja maupun keluarga saat mereka terpapar ancaman. Interaksi positif remaja dengan teman sebaya disarankan lebih ditingkatkan mengingat pengaruh teman sebaya di masa ini lebih kuat daripada pengaruh orang dewasa. Orang tua dan guru disarankan memberikan dukungan sarana kepada remaja untuk meningkatkan religiusitasnya. Pihak sekolah disarankan meningkatkan stimulus untuk remaja menerapkan nilai-nilai agama di sekolah dan membuat iklim sekolah yang lebih agamis. Bagi penelitian selanjutnya disarankan untuk memilih variabel-variabel lain yang dapat memperkaya kajian tentang faktor-faktor yang memengaruhi religiusitas seperti keterlibatan pemuka agama, komunitas, media sosial, 
religiusitas yang ditampilkan publik figure, sarana keagamaan, dan pengemasan agama yang lebih menarik. Selain itu, dengan melibatkan responden yang lebih beragam diharapkan dapat menggali faktor-faktor apa saja yang mempengaruhi religiusitas remaja.

\section{DAFTAR PUSTAKA}

Alwi, S. (2014). Perkembangan Religiusitas Remaja. Yogyakarta (ID): Kaukaba Dipantara.

Anshari, E.S. (1987). Kuliah Al-Islam: Pendidikan Agama Islam di Perguruan Tinggi. Bandung (ID): Pustaka.

Aprilia, N., Indrijati, H. (2014). Hubungan antara kecerdasan emosi dengan perilaku tawuran pada remaja laki-laki yang pernah terlibat tawuran di SMK 'B' Jakarta.Jurnal Psikologi Pendidikan dan Perkembangan, 3, 1-11.

Bahr, S.J., Maughan., Marcos, A.C., Li. (2014). Family, religiosity, and the risk of adolescent drug use. Journal of Marriage and Family, 60, 979-992.

Bliss, A. Ekmark, S.S., (2013). Gender differences in spirituality in persons in alcohol and drug dependence treatment. Routledge Taylor \& Francis Group, 31, 25-37, $10.1080 / 07347324.2013 .746625$

Bryant, A.N. (2007). Gender Differences in spiritual development during the college years. Sex Roles, 56, 835-846, DOI 10.1007/s11199-007-9240-2

Bukowski, M.W., Hoza, B., \& Boivin, M. (1994).Measuring friendship quality during pre and early adolescence: the development and pshycometric properties of the friendship qualities scale.Journal of Social and Personal Relationship, 11, 471-484.

Botchcovar, E., Marshall, I.H., Rocque, M., Posick, C. (2016). The importance of parenting in the development of self control in boys and girls: result from multinational study of youth. Journal of Criminal Justice, 43,133-141.

Borch, C., Hyde, A., Cillessen A.H.N. (2011). The role of attractiveness and aggression in high school popularity. Journal Social Psychologi of Education, 14, 23-39. DOI 10.1007/s11218-010-9131-1

Cheung, C., Yeung, J.W. (2011). Meta-analysis of relationships between religiosity and constructive and destructive behaviors among adolescents. Children and Youth Services Review. 33, 376-385

Dermawan. S., Sunarti, E., \& Herawati, T. (2018).Internalisasi nilai kebaikan melalui fungsi keagamaan dan pengondisian lingkungan dan dampaknya terhadap karakter anak.Jurnal IImu Keluarga \& Konsumen,10 (3):; 204-215, DOI: http: //dx.doi.org

$/ 10.24156$

/jikk.2017.10.3.204

Desrotser, A., Kelley, B.S., \& Miller, L. (2011). Parent and peer relationship and relational spirituality in adolescents and young adults. Psychology of Religion and Spirituality, $3, \quad 39-54$. doi:10.1037/a0020037

Fergus, S., Zimmerman.M.A. (2005). Adolescent resilience: a framework for understanding healthy development in the face of risk. Annual Review of Public Health,26, 399-419.

Furrow, J.L., King, P.E., White, K. (2004) Religion and positive youth development: identity, meaning, and prosocial concerns. Developmental Science, 8, 1726 ,

DOI:

10.1207/S1532480XADS0801_3

Glock, C.Y., \& Stark. R, (1968).American piety, patterns of religious commitment. Diambil dari www.books.google.com

Hackett, C., Murphy, C., \& Mc Clendon, D. (2016). The gender gap in religion around the world. Washington DC: Pew Research Center

Holder, M.D., Coleman, B., Krupa, T., \& Krupa, E (2015). Well being's relation to religiosity and spirituality in children and adolescents in Zambia. Journal Happiness Study.DOI 10.1007/s10902015-9640-x

Hurlock, E.B. (1993). Psikologi Perkembangan. Jakarta: Penerbit Erlangga

Junaidi, K. (2017). Pemberdayaan nilai-nilai institusi dan holistik education; kajian kontribusi pemimpin pendidikan terhadap gerakan revolusi mental.Jurnal Studi Kependidikan dan Keislaman, 07, 1-12.

Kaplan. (1999). Child and adolescent abuse and neglect research: a review of the past 10 years. Part I: Physical and emotional abuse and neglect. J. $A M$. Acad. Child Adolesc Psychiatry, 38, 1214-1222. 
King, E. P., \& Mueller, R.A. (2003). Parental influence on adolescent religiousness: exploring the roles of spiritual modeling and spiritual capital. Marriage and Family: AChristian Journal. 6 :401-13.

Kirsi, T., Nokelainen, \& Ubani, M. (2006). Conceptual definition and empirical validation of the spiritual sensitivity scale. Journal for Empirical Theology, 19, 3762.

Leonard, K.C., Boyatzis, C.J., Cook, K.V., Kimball, C.N., Flanagan, K.S. (2013). Parent-child dynamics and emerging adult religiosity: attachment, parental beliefs, and faith support. Journal Psychology of Religion and Spirituality. 5, 5-14. DOI: 10.1037/a0029404

Mukama. (2010). Peer group influence, alcohol consumption, and secondary school student attitudes towards school. (Disertation), Makerere University, Kampala, Uganda.

Najam, N., \& Batool, S. (2016). Relationship between perceived parenting style, perceived Parental Acceptance Rejection (PAR) and perception of God among young adults.Journal of Behavioural Sciences, 22, 83-99.

Nisfiannoor, M., \& Kartika, Y. (2004). Hubungan antara regulasi emosi dan penerimaan kelompok teman sebaya pada remaja. Jurnal Psikologi,2, 160178.

Petts, R.J. (2014). Parental religiosity and youth religiosity: variations by family structure. Journal Sociology of Religion, 76, 95120. doi:10.1093/socrel/sru064

Puspitasari, R., Hastuti, D., \& Herawati, T. (2016). Pengaruh kecerdasan spiritual ibu terhadap karakter anak usia sekolah dasar di perdesaan. Jurnal IImu Keluarga dan Konsumen, 9 (2) : 101-112

Rose, A.J., Smith, R,L., Glick, G.C., \& Mette, R.A. (2016). Girls' and boys' problem talk: implications for emotional closeness in friendships. Journal Developmental Psychology, 52, 629 - 639.

Santrock, J.W. (2007). Remaja.Jakarta: Penerbit Erlangga.

Sayidani, A., Irianto, W.S., Fuady, M.J. (2016). Perbandingan prestasi belajar mahasiswa lulusan SMA dan SMK pada prodi S1 pendidikan teknik informatika Universitas Negeri Malang. Jurnal Teknologi dan Kejuruan, 39, 155-162
Sub Direktorat Statistika Pendidikan dan Kesejahteraan Sosial. (2017). Statistik Pemuda Indonesia 2017. Jakarta: Badan Pusat Statistik.

Sunarti, E., Rochimah, N., \& Islamia, I. (2015). Laporan Kajian Resiliensi Anak: Potret, Faktor Rumusan Aksi Penguatannya. Jakarta (ID): Kementerian Pemberdayaan Perempuan dan Perlindungan Anak Republik Indonesia.

Sunarti, E., Rochimah, N., Islamia, I., Ulfa, M. (2017). Pengaruh faktor ekologi terhadap resiliensi remaja. Jurnal IImu Keluarga dan Konsumen, 10, 107-119. DOl: doi.org/10.24156/jikk.2017.10.2.107

Smith, C, \& Denton. (2005). Soul Searching: The Religious And Spiritual Lives Of American Teenagers. Oxford University Press, USA.

Schwartz, S.H. (2006). Basic human values: theory, measurment, and applications. Revue Francaise de Sociologi, 47, 981985.

Tasqiya, R. S., Hastuti, D., \& Puspitawati, H. (2018). Spiritual parenting: the difference between father and mother, and their influence on spiritual intelligence. Proceeding : The $1^{\text {st }}$ International Seminar on Family and Consumer Issues in Asia (ISFCI) " Challenging family in Asia: Present and Future", Bogor, $4^{\text {th }}$ September 2018, 108-113

Vermeer, P. (2014). Religion and family life: an overview of current research and suggestions for future research. Journal Religions, 5, 402-421. doi:10.3390/rel5020402.

Walker, L.J., Hennig, K.H., Krettenauer, T.(2000). Parent and peer contexts for children's moral reasoning development. Journal Child Development, 71, 10331048.

Wardhani, R., Sunarti, E., \& Muflikhati, I. (2017). Ancaman, faktor protektif, aktifitas, dan resiliensi remaja. Jurnal IImu Keluarga\& Konsumen, 10(1): 47-58.

Widianti, E. (2011). Pengaruh terapi logo dan terapi suportif kelompok terhadap ansietas remaja di rumah tahanan dan lembaga pemasyarakatan wilayah Provinsi Jawa Barat. (Tesis), Universitas Indonesia, Depok, Indonesia.

Zahra, N , Suherman, A, Permana, T. (2017). Pengaruh penerapan model pembelajaran kooperatif tipe student 
Vol. 12, 2019 KEBERFUNGSIAN AGAMA, ANCAMAN, INTERAKSI TEMAN, DAN RELIGIUSITAS 25

teams achievement division terhadap aktivitas, interaksi dan hasil belajar siswa SMK. Journal of Mechanical Engineering Education, 4, 213-218.
Zolkoski, S.M., Bullock, L.M.(2012). Resilience in children and youth: a review. Children and Youth Services Review, 34, 22952303.

doi.org/10.1016/j.childyouth.2012.08.00 9. 